\title{
Acclimatization of micropropagated seedlings of pineapple cultivars on organic substrates
}

\section{Aclimatação de mudas micropropagadas de cultivares de abacaxizeiro em substratos orgânicos}

\author{
Jefferson Bittencourt VENÂNCIO'; Wellington Farias ARAÚJO²; Edvan Alves CHAGAS ${ }^{3}$ \\ ${ }^{1}$ Autor para correspondência: doutorando do Programa de Pós-Graduação em Fitotecnia (PPGF) pela Universidade Federal \\ Rural do Semiárido - UFERSA, Av. Francisco Mota, 572 - Caixa Postal 137 - Bairro Presidente Costa e Silva - Mossoró - \\ RN - CEP: 59.625-900. E-mail: jeffersonbittencourtvenncio@gmail.com \\ ${ }^{2}$ DSc., professor titular da Universidade Federal de Roraima - UFRR, Programa de Pós-Graduação em Agronomia \\ (POSAGRO). E-mail: wellington.araujo@ufrr.br; \\ ${ }^{3}$ DSc., pesquisador da Embrapa Roraima. E-mail: echagas@cpafrr.embrapa.br. \\ Extraído da dissertação de mestrado do primeiro autor.
}

Recebido em: 13-07-2018; Aceito em: 23-10-2018

\begin{abstract}
Fusariosis constitutes an important hindrance to pineapple farming in Brazil. The cultivars resistant to fusariosis, 'Vitória' and 'Imperial', from in vitro culture, are an alternative for crop management. This work evaluates the vegetative performance of pineapple cultivars propagated by tissue culture in response to the use of organic substrates, different in nature and proportion. The experimental design was a completely randomized block, arranged in a $3 \times 5$ factorial scheme, with three pineapple cultivars ('Pérola', 'Vitória', and 'Imperial') and five substrates [ORG: Organoamazon ${ }^{\circledR}$, organic compound; SS: Standard Substrate, soil + sand (1:1 v/v); SS + M + C: SS + sheep manure $(M)+$ carbonized rice husk (C) $(2: 1: 1 \mathrm{v} / \mathrm{v}) ; \mathrm{SS}+\mathrm{M}(3: 1 \mathrm{v} / \mathrm{v}) ; \mathrm{SS}+\mathrm{C}(3: 1 \mathrm{v} / \mathrm{v})$, unfolded in mean contrasts]. The variables analyzed were shoot and root growth and shoot nutrient content. The vegetative performance of cultivars, considering the increase of shoot dry weight in the most responsive substrate, was: 'Pérola' > 'Vitória' > 'Imperial'. Substrate ORG promoted higher increases in shoot dry weight $(259 \%)$ and root density $(116 \%)$ compared to the average of the other substrates. The growth promoted by ORG resulted in higher $\mathrm{N}, \mathrm{P}, \mathrm{K}, \mathrm{Ca}$, and $\mathrm{Mg}$ content in pineapple plants. Substrates $\mathrm{ORG}$ and $\mathrm{SS}+\mathrm{M}+\mathrm{C}$ are recommended for acclimatization of in vitro propagated pineapple seedlings in the period of ex vitro seedling acclimatization.
\end{abstract}

Additional keywords: Ananas comosus var. comosus; pineapple cultivars 'Vitória', 'Pérola', and 'Imperial'; plant multiplication; plant tissue culture; micropropagation.

\begin{abstract}
Resumo
A fusariose constitui importante entrave na abacaxicultura brasileira. As cultivares resistentes à fusariose, Vitória e Imperial, oriundas do cultivo in vitro, vêm sendo alternativa de manejo cultural. Objetivou-se com este trabalho avaliar o desempenho vegetativo de cultivares de abacaxizeiros propagados por cultura de tecidos em resposta ao uso de substratos orgânicos, diferentes quanto a sua natureza e proporção. O delineamento experimental foi em blocos inteiramente casualizados, disposto em esquema fatorial $3 \times 5$, sendo três cultivares de abacaxizeiro ('Pérola', 'Vitória' e 'Imperial') e cinco substratos [ORG: Organoamazon®, composto orgânico; SP: Substrato Padrão, solo + areia $(1: 1 \mathrm{v} / \mathrm{v}) ; \mathrm{SP}+\mathrm{E}+\mathrm{C}$ : SP + esterco de carneiro $(\mathrm{E})$ + casca de arroz carbonizada (C) (2:1:1 $\mathrm{v} / \mathrm{v}) ; \mathrm{SP}+\mathrm{E}(3: 1 \mathrm{v} / \mathrm{v}) ; \mathrm{SP}+\mathrm{C}(3: 1 \mathrm{v} / \mathrm{v})$, avaliados pelo desdobramento em contrastes médios]. As variáveis analisadas foram o crescimento e o conteúdo de nutrientes na parte aérea da planta e o crescimento do sistema radicular. $\mathrm{O}$ desempenho vegetativo das cultivares, considerando o incremento de massa seca na parte aérea, no substrato mais responsivo, foi: 'Pérola' > 'Vitória' > 'Imperial'. O substrato ORG promoveu incrementos superiores na massa seca da parte aérea da planta $(259 \%)$ e na densidade do sistema radicular $(116 \%)$, em relação à média dos demais substratos. O crescimento promovido pelo ORG resultou em maior conteúdo de N, P, K, Ca e $\mathrm{Mg}$ nas plantas de abacaxizeiro. $\mathrm{O} O R G$ e $S P+E+C$ são recomendados para aclimatação de mudas de abacaxizeiros propagados in vitro, no período de aclimatação das plântulas, no ambiente ex vitro.
\end{abstract}

Palavras-chave adicionais: Ananas comosus var. comosus; abacaxizeiros 'Vitória', 'Pérola' e 'Imperial'; cultura de tecidos de plantas; micropropagação; multiplicação de plantas.

\section{Introduction}

Pineapple (Ananas comosus var. comosus) belongs to the family Bromeliaceae, of great economic importance in Brazil. Cultivars 'Pérola' and 'Smooth Cayenne' have greater commercial acceptance but are susceptible to fusariosis. Cultivars 'Vitória' and 'Impe- rial', in turn, launched by the Brazilian Agricultural Research Corporation (EMBRAPA), in 2006 and 2004, respectively, have been presented as an alternative for Brazilian producers (Viana et al., 2013; Berilli et al., 2014; Caetano et al., 2015). They show fusarium resistance, excellent agronomic characteristics, and good commercial acceptance. These cultivars have 
also been the subject of research, due to the need for knowledge about their acclimatization in different regions of the country.

The lack of quality and quantity seedlings for propagation has been one of the obstacles for pineapple farming in Brazil. In vitro culture is a strategy to mitigate the problem. The protocol for in vitro production of pineapple seedlings is well established (Araújo et al., 2008; Fráguas et al., 2009; Silva et al., 2012; Oliveira-Cauduro et al., 2016), allowing the production of uniform, healthy, and totally disease-free seedlings. After in vitro development, these seedlings need to be acclimatized under ex vitro conditions for subsequent planting under field conditions (Baldotto et al., 2009; Oliveira-Cauduro et al., 2016).

The acclimatization period of pineapple seedlings is necessary, since changes from in vitro to ex vitro conditions, such as heterotrophic to autotrophic metabolism and reduction of air humidity and nutrients, would limit field cultivation (Baldotto et al., 2009). In vitro cultured pineapple seedlings have little developed cuticles and low stomatal intensity (Barboza et al., 2006), characteristics unfavorable to the drastic variations inherent in the open-field environment.

Due to the need for an acclimatization period, many studies on types of containers; foliar application of macro- and micronutrients (Bregonci et al., 2008); application of humic acids; inoculation of endophytic and epiphytic diazotrophic bacteria (Baldotto et al., 2009, 2010); inoculation with mycorrhizal fungi (Santos et al., 2011); use of brassinosteroids; and substrate composition (Catunda et al., 2008) have been performed aiming to improve the performance in this phase of the process.

Substrate constituents vary greatly in the studies performed (Catunda et al., 2008; Cunha Filho et al., 2008; Oliveira-Cauduro et al., 2016; Mendonça et al., 2017), being common the use of organic materials. In general terms, substrate components are adjusted aiming at a suitable culture medium for shoot and root development, so that chemical (nutrient availability and $\mathrm{pH}$ ) and physical (porosity, texture, and structure) factors are in the proportions required by the plant species.

Mendonça et al. (2017) observed beneficial effects from the use of goat and bovine manure on the substrate composition for acclimatization of micropropagated seedlings of pineapple cultivars 'Vitória' and 'Imperial'. Working with humic acids (HA) (product of biodegradation of organic materials), Baldotto et al. (2009) reported significant effects of HA doses on shoot and root growth; N, P, K, Ca, and Mg accumulation; and chlorophyll $\mathrm{a} / \mathrm{b}^{-1}$ ratio of micropropagated seedlings of pineapple cv. 'Vitória'.

This work evaluates the performance of micropropagated seedlings of pineapple cultivars 'Pérola', 'Vitória', and 'Imperial' regarding plant growth and macronutrient accumulation, in substrates with different compositions of organic material.

\section{Materials and methods}

The experiment was conducted in a greenhouse located at Embrapa Roraima, Boa Vista-RR, Brazil, whose geographic coordinates are 020 42' 30" N and $47^{\circ} 38^{\prime} 00^{\prime \prime} \mathrm{W}$, at $90 \mathrm{~m}$ altitude. According to the Köppen classification, the climate is Aw, with rainy period from mid-April to September, average annual rainfall of $1688 \mathrm{~mm}$, air temperature of $27.7^{\circ} \mathrm{C}$, and relative air humidity of $79 \%$.

The experimental design was a completely randomized block with four replicates and four plants per experimental unit, totaling 16 plants per treatment. The treatments were arranged in a $3 \times 5$ factorial scheme, consisting of three pineapple cultivars (Pérola; Vitória; Imperial) and five substrates [ORG: Organoamazon ${ }^{\circledR}$, commercial organic compound based on cattle, horse, chicken, and sheep manure, aged and carbonized rice straw, peat, sugarcane bagasse, grass clippings, galls and foliage; SS: Standard Substrate, composed of soil classified as Yellow Latosol, typical of the savannahs of Roraima, plus sand, in the ratio 1:1 (v/v); SS + M + C: composed of SS + sheep manure $(\mathrm{M})+$ carbonized rice husk (C) $(2: 1: 1 \mathrm{v} / \mathrm{v}) ; \mathrm{SS}+\mathrm{M}$ : composed of SS + M (3:1 $\mathrm{v} / \mathrm{v}) ; \mathrm{SS}+\mathrm{C}$ : composed of SS + C (3:1 v/v)], whose chemical and physical properties are presented in Table 1 and 2. The commercial organic compound (ORG), developed by Norte Flora Paisagismo and analyzed by Embrapa, constitutes a $100 \%$ natural and regional organic fertilizer.

Table 1 - Chemical analysis of the substrates used for the performance test of the pineapple cultivars.

\begin{tabular}{|c|c|c|c|c|c|c|c|c|c|c|c|c|c|}
\hline \multirow{3}{*}{ Subst $^{(1)}$} & & \multicolumn{8}{|c|}{ Sortive complex ${ }^{(2)}$} & \multirow{2}{*}{\multicolumn{2}{|c|}{$\mathrm{V} \quad \mathrm{N}$}} & & \multirow[b]{2}{*}{ OM } \\
\hline & & $\mathrm{Ca}^{2+}$ & $\mathrm{Mg}^{2+}$ & $\mathrm{K}^{+}$ & $\mathrm{Al}^{3+}$ & $\mathrm{H}+\mathrm{Al}$ & $S$ & $\mathrm{t}$ & $\mathrm{T}$ & & & & \\
\hline & & & & & 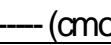 & $\left.\mathrm{cdm}^{-3}\right)$ & & & & & & & \\
\hline & & & & & - & & & & & & & & \\
\hline & & & & & 0.10 & & & & & & 1. & & \\
\hline & $5 .($ & J & 3.2 & 1 & - & 1. & 6. & 6. & 37 & & - & & 22.30 \\
\hline & 4. & 2.80 & 2.4 & 0.53 & 0.10 & 2. & 5.73 & 5.83 & 8.32 & 68.91 & 1.7 & & 26.10 \\
\hline & 0.0 & 1.10 & 0.50 & 0.31 & 0.10 & 1.66 & 1.91 & 2.01 & 3.57 & 53.44 & 4.98 & 17.51 & 11.80 \\
\hline
\end{tabular}

(1) Substrates: ORG: Organoamazon $\AA$, commercial organic compound based on livestock manure, horse, chicken and sheep, aged and charred rice straw, peat, sugar cane bagasse and grass, gills and foliage; SS: Standard substrate, composed of soil from the savannah + sand, in a ratio of $1: 1(\mathrm{v} / \mathrm{v}) ; \mathrm{SS}+\mathrm{M}+\mathrm{C}$ : composed of SS + sheep manure - M + carbonized rice husk C (2: 1: 1); SS + M: composed of SS + M (3: 1); SS + C: composed of SS + C (3: 1); (2) pH in water (1: 2.5); $\mathrm{Ca}^{2+}, \mathrm{Mg}^{2+}$ and $\mathrm{Al}^{3+}$ : extractor $\mathrm{KCl} 1$ mol L-1; $\mathrm{K}^{+}$and $\mathrm{P}$ : extractor mehlich-1; $\mathrm{H}+\mathrm{Al}$ : SMP extractor; OM: organic matter - oxidation $\mathrm{Na}_{2} \mathrm{Cr}_{2} \mathrm{O}_{7} 4 \mathrm{~N}$ $+\mathrm{H}_{2} \mathrm{SO}_{4} 10 \mathrm{~N}$; S: sum of exchangeable bases; t: effective cation exchange capacity (CEC); T: $\mathrm{CEC}$ at pH 7.0; V: base saturation index; m: saturation index by aluminum. 
Table 2 - Micronutrients and granulometry of the substrates used for the performance test of the pineapple cultivars.

\begin{tabular}{|c|c|c|c|c|c|c|c|c|c|}
\hline \multirow[b]{2}{*}{ Subst $^{(1)}$} & \multicolumn{6}{|c|}{ Micronutrients(2) $^{(2)}$} & \multicolumn{3}{|c|}{ Granulometry } \\
\hline & $\mathrm{Zn}$ & $\mathrm{Fe}$ & $\begin{array}{l}\mathrm{Mn} \\
-\end{array}$ & $\begin{array}{c}\mathrm{Cu} \\
\left.\mathrm{m}^{-3}\right)\end{array}$ & B & $S$ & Clay & $\begin{array}{c}\text { Silt } \\
\left(\mathrm{a} \mathrm{kg}^{-1}\right.\end{array}$ & Sand \\
\hline$\overline{\mathrm{ORG}}$ & 19.47 & 27.08 & 123.96 & 0.34 & 0.33 & 19.40 & 170 & 290 & 540 \\
\hline SS & 2.19 & 34.70 & 19.72 & 0.63 & 0.04 & 9.91 & 120 & - & 880 \\
\hline$S S+M+C$ & 5.12 & 9.64 & 27.90 & 0.42 & 0.43 & 8.64 & 130 & 100 & 770 \\
\hline $\mathrm{SS}+\mathrm{M}$ & 5.28 & 17.95 & 30.38 & 0.56 & 0.45 & 24.45 & 110 & 40 & 850 \\
\hline $\mathrm{SS}+\mathrm{C}$ & 3.49 & 25.85 & 22.39 & 0.91 & 0.17 & 25.14 & 110 & 50 & 840 \\
\hline
\end{tabular}

(1) Substrates: ORG: Organoamazon®, commercial organic compound based on livestock manure, horse, chicken and sheep, aged and charred rice straw, peat, sugar cane bagasse and grass, gills and foliage; SS: Standard substrate, composed of soil from the savannah + sand, in a ratio of $1: 1(\mathrm{v} / \mathrm{v})$; SS + M + C: composed of SS + sheep manure - M + carbonized rice husk C (2: 1: 1); SS + M: composed of SS + M (3: 1); SS + C: composed of SS + C (3: 1); (2) Zn, Fe, Mn and Cu: mehlich-1 extractor; $\mathrm{B}$ : extractor hot water; $\mathrm{S}$ : monocalcium phosphate extractor in acetic acid.

Pineapple (Ananas comosus var. comosus) seedlings, propagated in vitro in $200 \mathrm{ml}$ plastic pots, were purchased from the Biotechnology Laboratory of the Company Bioclone Produção de Mudas LTDA ${ }^{\circledR}$. In vitro seedlings were maintained in test tubes containing MS medium (Murashige \& Skoog, 1962) without growth regulators and vitamins, with replacements every three months. The growth room was maintained under photosynthetic photon flux of $25 \mu \mathrm{mol} \mathrm{m} \mathrm{m}^{-2} \mathrm{~s}^{-1}$, temperature of $25 \pm 2{ }^{\circ} \mathrm{C}$, and photoperiod of $16 \mathrm{~h}$. The experimental stage was carried out with seedlings under preacclimatization conditions $(5 \pm 2 \mathrm{~cm})$, which were stored in refrigerated and moist styrofoam boxes.

Micropropagated pineapple seedlings were grown under greenhouse conditions, under controlled temperature $\left(28 \pm 2{ }^{\circ} \mathrm{C}\right)$ and relative air humidity (80\%), from June 2011 to February 2012. Substrates were subjected to 48-h fumigation with commercial product BUNEMA $330 \mathrm{CS}^{\circledR}$, at the dose of $350 \mathrm{~mL} \mathrm{~m}^{-3}$, using a 7-day grace period. After fumigation, the substrates were packed in black polyethylene bags with a capacity of $1.08 \mathrm{dm}^{3}$ for subsequent planting of seedlings. Irrigation, with $35 \mathrm{~L} \mathrm{~h}^{-1}$ nebulizers at a pressure of $147,15 \mathrm{kPa}\left(1.5 \mathrm{kgf} \mathrm{cm}^{-2}\right)$, was performed with three daily 2-min waterings, aiming at a daily depth of $3.5 \mathrm{~mm}$.

At 210 days of acclimatization, the perfor- mance of pineapple plants grown on different substrates was evaluated for the following variables: number of leaves (NL); shoot height (SH) (cm); stem diameter (SD) (mm); leaf area (LA) $\left(\mathrm{cm}^{2}\right)$; shoot fresh weight (SFW), shoot dry weight (SDW) (g); root density (RD) $\left(\mathrm{g} \mathrm{dm}^{-3}\right)$; and root:shoot ratio (RSR). For measuring LA, a benchtop leaf area meter (model LI-3100, LI-COR, Nebraska, USA) was used. Weighing measures were obtained in a SHIMADZU ${ }^{\circledR}$ BL3200H scale. Dry matter was determined after drying the plants in a forced air circulation oven at $60^{\circ} \mathrm{C}$ for seven days, until constant weight.

After weighing the dried plants, a composite sample was formed from the four plants of each replicate. Subsequently, the material was ground in a Wiley mill with a 20-mesh sieve and stored in hermetically sealed vials. Total $\mathrm{N}, \mathrm{P}, \mathrm{K}, \mathrm{Ca}$, and $\mathrm{Mg}$ contents were obtained according to the method proposed by Malavolta et al. (1997). Plant nutrient content was obtained by multiplying the contents by the SDW production.

The variables were subjected to analysis of variance by the $F$ test $(p<0.05)$. The effects of treatments, when significant $(p<0.05)$, were unfolded in mean contrasts (Table 3) (Alvarez V. \& Alvarez, 2006) for the factor substrates, while the Tukey test $(p<0.05)$ was used for the factor cultivar.

Table 3 - Coefficients of the studied contrasts for the substrates factor.

\begin{tabular}{lcccc}
\hline Substrates $^{(1)}$ & \multicolumn{2}{c}{ Contrasts coefficients } & \\
& C1 & C2 & C3 & C4 \\
\hline ORG & +4 & 0 & 0 & 0 \\
SS & -1 & +3 & 0 & 0 \\
SS+M+C & -1 & -1 & +2 & 0 \\
SS+M & -1 & -1 & -1 & +1 \\
SS+C & -1 & -1 & -1 & -1 \\
\hline
\end{tabular}

(1)Substrates: ORG: Organoamazon®, commercial organic compound based on livestock manure, horse, chicken and sheep, aged and charred rice straw, peat, sugar cane bagasse and grass, gills and foliage; SS: Standard substrate, composed of soil from the savannah + sand, in a ratio of $1: 1(\mathrm{v} / \mathrm{v}) ; \mathrm{SS}+\mathrm{M}+\mathrm{C}$ : composed of $\mathrm{SS}+$ sheep manure $-\mathrm{M}+$ carbonized rice husk C (2: 1: 1); SS + M: composed of SS + M (3: 1); SS + C: composed of SS + C (3: 1); (2)Contrasts: C1: ORG vs SS: organic compound (ORG) vs group of substrates involving those with standard substrate - SS (SS, SS + M + C, SS + M, SS + C);

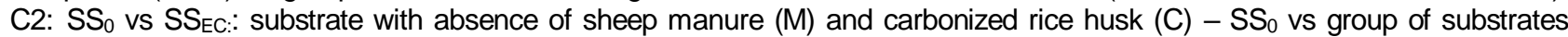
involving those with $\mathrm{M}$ and, or, $C$ components $-\mathrm{SS}_{\mathrm{MC}}(\mathrm{SS}+\mathrm{M}+\mathrm{C}, \mathrm{SS}+\mathrm{M}, \mathrm{SS}+\mathrm{C})$; $\mathrm{C} 3$ : $\mathrm{SS}_{\mathrm{M}+\mathrm{C}}$ vs $\mathrm{SS}_{\mathrm{MC}}$ : substrate with $\mathrm{M}$ and $C$ components $-S S_{M+C}(S S+M+C)$ vs group of substrates involving those with $M$ or $C$ components $-S S_{M C}(S S+M, S S$ $+C) ; C 4: S S_{M}$ vs $S_{C}$ : substrate with $M$ component $-S_{M}(S S+M)$ vs substrate with $C$ component $-S S_{C}(S S+C)$. 


\section{Results and discussion}

Regarding shoot and root morphological characteristics and nutrient content, micropropagated pineapple cultivars 'Pérola', 'Vitória', and Imperial interacted significantly, during acclimatization, with the substrates of different compositions (Tables 4, 5 and 6).
At 210 days of acclimatization, treatments standard substrate (SS) and standard substrate with carbonized rice husk $(\mathrm{SS}+\mathrm{C})$ showed plant height $(\mathrm{PH})$ below $(\leq 13.8 \mathrm{~cm})$ the $20-30 \mathrm{~cm}$ recommended for field planting (Berilli et al., 2011; Mendonça et al., 2017) (Table 4).

Table 4 - Shoot and root growth of the 'Pérola', 'Vitória' and 'Imperial' pineapples as function of the substrate.

\begin{tabular}{|c|c|c|c|c|c|c|c|c|}
\hline Cultivar & $\mathrm{NL}$ & $\begin{array}{l}\mathrm{PH} \\
(\mathrm{cm})\end{array}$ & $\begin{array}{l}\mathrm{SD} \\
(\mathrm{mm})\end{array}$ & $\begin{array}{l}\text { SFM } \\
---(g \text { plant }\end{array}$ & $\begin{array}{l}\text { SDM } \\
\left.\mathrm{t}^{-1}\right)--- \\
\end{array}$ & $\begin{array}{c}\mathrm{LA} \\
\left(\mathrm{cm}^{2}\right)\end{array}$ & $\begin{array}{c}\mathrm{RD} \\
\left(\mathrm{g} \mathrm{dm}^{-3}\right)\end{array}$ & $\begin{array}{c}\mathrm{RS} \\
\left(\mathrm{g} \mathrm{g}^{-1}\right)\end{array}$ \\
\hline & & & & קח & ใG ------ & 001001 & -7 & \\
\hline Pérola & $26 b^{1}$ & $69.6 a$ & $22.80 \mathrm{~b}$ & $334.70 \mathrm{a}$ & $46.94 a$ & $3,848.21 a$ & $7.43 a$ & $0.17 a$ \\
\hline Vitória & $28 a$ & $67.8 \mathrm{a}$ & $24.11 a$ & $313.47 b$ & $32.91 b$ & $2,683.24 b$ & $6.53 b$ & $0.21 a$ \\
\hline Imperial & $24 c$ & $60.9 b$ & $23.28 \mathrm{~b}$ & 249.57c & $28.26 \mathrm{c}$ & $2,533.11 c$ & $3.54 \mathrm{c}$ & $0.13 a$ \\
\hline Pérola & $14 a$ & $10.0 \mathrm{a}$ & $7.36 \mathrm{a}$ & $9.79 a$ & $1.31 \mathrm{a}$ & $69.97 a$ & $1.51 \mathrm{a}$ & $1.25 b$ \\
\hline Vitória & $14 a$ & $10.3 a$ & $8.13 a$ & $9.32 \mathrm{a}$ & $1.08 \mathrm{a}$ & $82.12 a$ & $1.65 a$ & $1.63 a$ \\
\hline Imperial & $14 a$ & $9.3 a$ & $7.57 a$ & $8.21 a$ & $1.06 a$ & $70.61 a$ & $1.02 b$ & $1.05 c$ \\
\hline Pérola & $24 b$ & $49.8 \mathrm{a}$ & 19.79ab & $188.22 a$ & $23.50 \mathrm{a}$ & $2,029.54 a$ & $3.94 a$ & $0.18 \mathrm{a}$ \\
\hline Vitória & $27 a$ & $42.8 \mathrm{c}$ & $20.29 a$ & $180.86 a$ & $20.08 b$ & $1,364.01 \mathrm{c}$ & $3.18 b$ & $0.17 a$ \\
\hline Imperial & $23 b$ & $45.0 \mathrm{~b}$ & $19.30 \mathrm{~b}$ & $146.24 b$ & $16.31 \mathrm{c}$ & $1,458.92 b$ & $2.24 \mathrm{c}$ & $0.15 a$ \\
\hline Pérola & $20 c$ & $38.2 \mathrm{a}$ & $16.45 a$ & $113.98 \mathrm{a}$ & $13.34 a$ & $1,122.81 a$ & $3.38 a$ & $0.27 \mathrm{a}$ \\
\hline Vitória & $25 a$ & $36.3 b$ & $16.85 a$ & $116.74 a$ & $12.27 \mathrm{~b}$ & $1,041.15 a b$ & $2.16 \mathrm{~b}$ & $0.19 a$ \\
\hline Imperial & $23 b$ & $33.2 \mathrm{c}$ & $16.93 a$ & $102.04 b$ & $11.55 \mathrm{~b}$ & $966.29 b$ & $1.92 b$ & $0.18 a$ \\
\hline Pérola & $16 b$ & $13.8 a$ & $9.56 b$ & $18.63 a$ & $2.13 a$ & 193.98a & $1.53 a$ & $0.79 a$ \\
\hline Vitória & $18 a$ & $11.7 b$ & $10.83 a$ & $18.10 a$ & $2.19 a$ & $103.21 b$ & $1.39 a$ & $0.69 \mathrm{ab}$ \\
\hline Imperial & $18 a$ & $12.0 \mathrm{~b}$ & $11.11 \mathrm{a}$ & $19.88 a$ & $2.57 a$ & $158.45 \mathrm{ab}$ & $1.37 a$ & $0.58 b$ \\
\hline
\end{tabular}

NL: number of leaves; PH: plant height; SD: stem diameter; SFM: shoot fresh mass; SDM: shoot dry mass; LA: leaf area. RD: root density; RS: ratio between root and shoot dry mas. Substrates: ORG: Organoamazon $\Theta$, commercial organic compound based on livestock manure, horse, chicken and sheep, aged and charred rice straw, peat, sugar cane bagasse and grass, gills and foliage; SS: Standard substrate, composed of soil from the savannah + sand, in a ratio of $1: 1(\mathrm{v} / \mathrm{v}) ; \mathrm{SS}+\mathrm{M}+$ + C: composed of SS + sheep manure - M + carbonized rice husk - C (2: 1: 1); SS + M: composed of SS + M (3: 1); $S S+C$ : composed of $S S+C$ (3: 1). Within each substrate, means followed by the same letter in the column do not differ by Tukey test $(p>0.05)$.

The physical and chemical characteristics resulting from the combination of components of substrates SS and SS + C provided low levels of fertility and organic matter, high levels of toxic elements $\mathrm{H}^{+}$ and $\mathrm{Al}^{3+}$, and high grain size in the sand fraction (Tables 1 and 2). Thus, these substrate arrangements were unable to supply water and minerals to the pineapple cultivars in the proportions required by the plant species for a production of seedlings in satisfactory conditions for field planting.

The use of sheep manure as a component of the substrates $(\mathrm{SS}+\mathrm{M}$ and $\mathrm{SS}+\mathrm{M}+\mathrm{C}$ ) provided $\mathrm{PH}>$ $33.2 \mathrm{~cm}$ (Table 4). Regarding shoot growth, cv. 'Pérola' was superior in $\mathrm{PH}$, while $\mathrm{cv}$. 'Vitória' showed higher number of leaves (NL) (Table 4). These results were higher than those observed by Mendonça et al. (2017), who, at 270 days of acclimatization, verified $\mathrm{PH}$ of 19.6 and $20 \mathrm{~cm}$ and NL of 19.2 and 20.6 leaves, for cultivars 'Vitória' and 'Imperial', respectively, in substrate composed of soil and goat manure $(1: 1 \mathrm{v} / \mathrm{v})$. The authors verified a better morphological performance of cv. 'Imperial' compared to cv. 'Vitória' for the variables $\mathrm{PH}$ and $\mathrm{NL}$, these results contrasting with those obtained in this experiment.

Cultivar 'Vitória' is the result of a recurrent clonal selection of the hybrid PRI ('Primavera') $\times$ SC-08 ('Smooth Cayenne') (Ventura et al, 2009). Its performance was documented as similar or superior in agronomic characteristics when compared to the traditional cultivars 'Pérola' and 'Smooth Cayenne'. As for the cultivar 'Imperial', few studies have documented its physiological performance. Sampaio et al. (2011) verified lower growth of cv. 'Imperial' compared to 'Jupi' and 'Gold', but the values were similar to 'Smooth Cayenne' and 'Gomo de Mel'. Caetano et al. (2015) discussed the slow growth of cultivar 'Imperial', which could justify the lower growth rates obtained in this experiment for the cultivar in question.

In substrates $S S+M$ and $S S+M+C$, cultivars 'Pérola' and 'Vitória' did not differ statistically from each other for shoot fresh weight (SFW), but were superior to cultivar 'Imperial'. For shoot dry weight 
(SDW) and leaf area (LA), the highest values occurred in cultivar 'Pérola'. Regarding the root system, there was a higher root density (DR) for cultivar 'Pérola', but the root:shoot dry weight ratio (RSR) did not differ among cultivars. Regarding fresh and dry biomass production, the superiority of cultivar 'Pérola' compared to other pineapple cultivars is widely recorded in the literature. Rodrigues et al. (2010) demonstrated superiority of cultivar 'Pérola' compared to 'Smooth Cayenne' for this variable; Santos et al. (2011), in turn, verified superiority regarding mean shoot weight in the production of 'Pérola' seedlings compared to 'Smooth Cayenne' and 'Jupi'; and Reinhardt et al. (2002) reported higher fresh and dry weight of cultivar 'Pérola' compared to 'Smooth Cayenne'. The higher vegetative vigor of 'Pérola' pineapple plants may be a genetic standard characteristic of this cultivar. Reinhardt et al. (2002), analyzing separately each organ of the plant, verified several differences when comparing cultivars 'Pérola' and 'Smooth Cayenne'. Cultivar 'Pérola' presented leaves of greater weight, length, and width. Cultivar 'Smooth Cayenne', in turn, showed a more developed stem and root system, higher number of leaves (which were less erect), smaller overall plant size, and slightly lower values of fresh and dry weight.

The use of organic compound Organoamazon ${ }^{\circledR}$ (ORG) provided pineapple cultivars with $\mathrm{PH}$ over $60.9 \mathrm{~cm}$, value two to three times higher than the $20-30 \mathrm{~cm}$ adopted by Mendonça et al. (2017) and Berilli et al. (2011), ideal for field planting (Table 4).

In substrate ORG, for the variables SFW, SDW, and LA, cultivars presented the following growth pattern: 'Pérola' > 'Vitória' > 'Imperial'. For PH, 'Pérola' was similar to 'Vitória', but superior to 'Imperial' (Table 4). However, for the variables NL and stem diameter (SD), the highest values were found for 'Vitória' (28 leaves and $24.11 \mathrm{~mm}$ stem diameter). In ORG, the pattern 'Pérola' > 'Vitória' > 'Imperial' was also verified for root density (RD), but there was no statistical difference between cultivars for the variable RSR.

The nutrient accumulation by cultivars 'Pérola', 'Vitória', and 'Imperial' is presented in Table 5. In ORG, the accumulation pattern presented by these cultivars was: 'Pérola' > 'Imperial' > 'Vitória', for $\mathrm{N}$ and $\mathrm{P}$; and 'Pérola' > 'Vitória' > 'Imperial', for $\mathrm{K}, \mathrm{Ca}$, and $\mathrm{Mg}$. The comparative nutritional performance between pineapple cultivars 'Pérola', 'Vitória', and 'Imperial' is not yet reported in the literature. However, Mendonça et al. (2017), working with 'Vitória' and 'Imperial', verified greater contribution of $\mathrm{N}, \mathrm{P}$, and $\mathrm{K}$ for cultivar 'Vitória', while a greater contribution of $\mathrm{Ca}$ and $\mathrm{Mg}$ was observed for cultivar 'Imperial', at 270 days of acclimatization.

Table 5 - Nutrient accumulation by 'Pérola', 'Vitoria' and 'Imperial' pineapples as function of the substrate.

\begin{tabular}{|c|c|c|c|c|c|}
\hline \multirow[b]{2}{*}{ Cultivar } & \multicolumn{5}{|c|}{ Nutrient accumulation } \\
\hline & $N$ & $P$ & $\mathrm{~K}$ & $\mathrm{Ca}$ & $\mathrm{Mg}$ \\
\hline & \multicolumn{5}{|c|}{ ORG } \\
\hline Pérola & $347.33 a$ & $129.07 a$ & $386.16 \mathrm{a}$ & $520.94 a$ & $190.08 a$ \\
\hline Vitória & $250.94 c$ & $65.79 c$ & $302.83 b$ & $251.65 b$ & $102.63 \mathrm{~b}$ \\
\hline Imperial & $284.96 b$ & $95.38 b$ & $\begin{array}{l}248.00 \mathrm{c} \\
\text { SS }\end{array}$ & $231.26 b$ & $82.57 \mathrm{c}$ \\
\hline Pérola & $6.46 a$ & $2.24 \mathrm{a}$ & $4.64 a$ & $12.11 \mathrm{a}$ & $3.63 a$ \\
\hline Vitória & $5.86 a$ & $1.76 a$ & $3.88 a$ & $10.78 \mathrm{a}$ & $3.21 \mathrm{a}$ \\
\hline \multirow[t]{2}{*}{ Imperial } & $5.62 a$ & $1.61 \mathrm{a}$ & $3.05 a$ & $9.64 a$ & $3.50 a$ \\
\hline & \multicolumn{5}{|c|}{$\mathrm{SS}+\mathrm{M}+\mathrm{C}$} \\
\hline Pérola & $223.29 b$ & $86.36 a$ & $54.63 b$ & $147.26 \mathrm{a}$ & $86.96 a$ \\
\hline Vitória & $244.81 a$ & $90.85 a$ & $31.59 c$ & $101.60 \mathrm{a}$ & $74.20 \mathrm{~b}$ \\
\hline \multirow[t]{2}{*}{ Imperial } & $188.48 c$ & $58.73 b$ & $137.47 \mathrm{a}$ & $106.97 a$ & $56.28 c$ \\
\hline & \multicolumn{5}{|c|}{$\mathrm{SS}+\mathrm{M}$} \\
\hline Pérola & $164.30 \mathrm{a}$ & $57.54 a$ & $31.64 b$ & $152.64 a$ & $59.09 a$ \\
\hline Vitória & $166.07 a$ & $55.02 a b$ & $06.35 c$ & $138.77 a$ & $55.41 \mathrm{a}$ \\
\hline \multirow[t]{2}{*}{ Imperial } & 166.21a & $52.25 b$ & $66.87 a$ & $109.77 a$ & $45.75 b$ \\
\hline & \multicolumn{5}{|c|}{$\mathrm{SS}+\mathrm{C}$} \\
\hline Pérola & $13.79 a$ & $10.66 a$ & $14.84 a$ & $17.44 a$ & $8.03 a$ \\
\hline Vitória & $13.06 a$ & $9.34 a$ & $13.77 a$ & $21.42 \mathrm{a}$ & $8.91 \mathrm{a}$ \\
\hline Imperial & $14.37 a$ & $9.94 a$ & $18.16 \mathrm{a}$ & $19.12 \mathrm{a}$ & $8.92 a$ \\
\hline
\end{tabular}

$\mathrm{N}, \mathrm{P}, \mathrm{K}, \mathrm{Ca}$, and $\mathrm{Mg}$ represent the nutrients nitrogen, phosphorus, potassium, calcium and magnesium, respectively. Substrates: ORG: Organoamazon $\circledast$, commercial organic compound based on livestock manure, horse, chicken and sheep, aged and charred rice straw, peat, sugar cane bagasse and grass, gills and foliage; SS: Standard substrate, composed of savannah soil + sand, in a ratio of $1: 1(\mathrm{v} / \mathrm{v}) ; \mathrm{SS}+\mathrm{M}+\mathrm{C}$ : composed of $S S+$ sheep manure $-M+$ carbonized rice husk - C (2:1:1); SS + M: composed of SS + M (3: 1); SS + C: composed of SS + C (3: 1); ${ }^{1}$ Within each substrate, means followed by the same letter in the column do not differ by Tukey test $(p>0.05)$. 
Table 6 - Average contrasts, relative increments, average square of residue (ASR) and coefficient of variation (CV) for the shoot and root growth of 'Pérola', 'Vitória' and 'Imperial' pineapples in response to treatments of the substrate factor.

\begin{tabular}{|c|c|c|c|c|c|c|c|c|c|}
\hline \multirow{3}{*}{ Causes of variation } & \multicolumn{9}{|c|}{ Average contrasts (relative increments, \%) } \\
\hline & \multirow[t]{2}{*}{ FD } & \multirow[t]{2}{*}{$\mathrm{NL}$} & \multirow[b]{2}{*}{$(\mathrm{cm})$} & \multirow{2}{*}{$\begin{array}{c}\mathrm{SD} \\
(\mathrm{mm})\end{array}$} & \multirow{2}{*}{\multicolumn{2}{|c|}{$---\left(\right.$ g plant $\left.^{-1}\right)$---- }} & \multirow{2}{*}{$\begin{array}{c}\mathrm{LA} \\
\left(\mathrm{cm}^{2}\right)\end{array}$} & \multirow{2}{*}{$\begin{array}{c}\mathrm{RD} \\
\left(\mathrm{g} \mathrm{dm}^{-3}\right)\end{array}$} & \multirow{2}{*}{$\begin{array}{c}\mathrm{RS} \\
\left(\mathrm{g} \mathrm{g}^{-1}\right)\end{array}$} \\
\hline & & & & & & & & & \\
\hline & & & & -------- & 'P & Śrola' --------- & ----------------- & & \\
\hline ORG vs SS's & 1 & $7.62(41)$ & $41.60(149)$ & $9.52(72)$ & $252.05(305)$ & $36.87(366)$ & $2,994.14(351)$ & $4.83(187)$ & $-0.45(266)$ \\
\hline $\mathrm{SS}_{0}$ vs $\mathrm{SS}_{\mathrm{MC}}$ & 1 & $-6.42(43)$ & $-23.99(239)$ & $-7.91(107)$ & $-97.15(992)$ & $-11.68(892)$ & $-1,045.48(1,494)$ & $-1.44(95)$ & $0.84(202)$ \\
\hline $\mathrm{SS}_{\mathrm{M}+\mathrm{C}}$ vs $\mathrm{SP}_{\mathrm{M} / \mathrm{C}}$ & 1 & $5.66(33)$ & 23.83(92) & $6.78(52)$ & $121.91(184)$ & 15.76(204) & $1,371.14(208)$ & $1.49(60)$ & $-0.35(194)$ \\
\hline \multirow[t]{2}{*}{$\mathrm{SS}_{\mathrm{M}}$ vs $\mathrm{SS}_{\mathrm{C}}$} & 1 & $3.56(25)$ & $24.28(177)$ & $6.88(72)$ & $95.34(512)$ & $11.20(526)$ & $928.83(479)$ & $1.85(121)$ & $-0.51(193)$ \\
\hline & & & \multicolumn{7}{|c|}{ 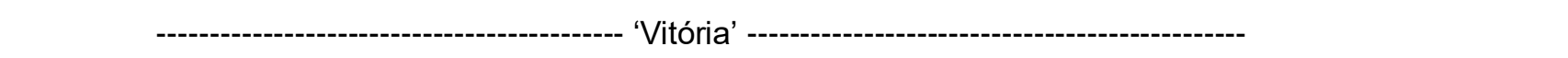 } \\
\hline ORG vs SS & 1 & $6.77(33)$ & $42.56(168)$ & $10.09(72)$ & $232.22(286)$ & 24.01(270) & $2,035.62(314)$ & $4.44(212)$ & $-0.45(219)$ \\
\hline $\mathrm{SS}_{0}$ vs SS $\mathrm{S}_{\mathrm{MC}}$ & 1 & $-9.40(67)$ & $-20.00(194)$ & $-7.87(97)$ & $-95.91(1,029)$ & $-10.43(966)$ & $-754.00(918)$ & $-0.59(36)$ & $1.28(366)$ \\
\hline $\mathrm{SS}_{\mathrm{M}+\mathrm{C}}$ vs $\mathrm{SS}_{\mathrm{M} / \mathrm{C}}$ & 1 & $5.03(26)$ & $18.75(78)$ & $6.45(47)$ & $113.44(168)$ & $12.85(178)$ & $791.82(138)$ & $1.41(79)$ & $-0.27(159)$ \\
\hline \multirow[t]{2}{*}{$\mathrm{SS}_{\mathrm{M}}$ vs $\mathrm{SS}_{\mathrm{C}}$} & 1 & $7.19(39)$ & $24.62(210)$ & $6.03(56)$ & $98.64(545)$ & $10.09(460)$ & 937.95(909) & $0.77(55)$ & $-0.50(263)$ \\
\hline & & & \multicolumn{7}{|c|}{ 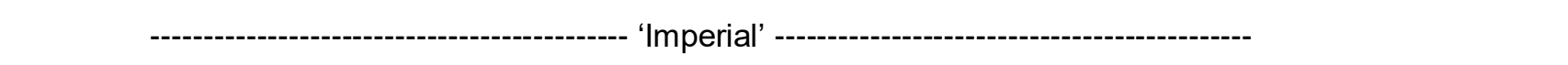 } \\
\hline ORG vs SS & 1 & $4.84(23)$ & $36.04(145)$ & $9.55(70)$ & $180.48(261)$ & 20.39(259) & $1,869.54(282)$ & $1.90(116)$ & $-0.35(277)$ \\
\hline $\mathrm{SS}_{0}$ vs SS $\mathrm{S}_{\mathrm{MC}}$ & 1 & $-7.04(52)$ & $-20.75(223)$ & $-8.21(108)$ & $-81.18(989)$ & $-9.09(857)$ & $-790.61(1,120)$ & $-0.82(81)$ & $0.74(246)$ \\
\hline$S_{S_{M+C}}$ vs $S S_{M / C}$ & 1 & $3.22(12)$ & $22.38(99)$ & $5.28(38)$ & $85.28(140)$ & $9.25(131)$ & $896.55(159)$ & $0.60(36)$ & $-0.23(153)$ \\
\hline $\mathrm{SS}_{\mathrm{M}} v s \mathrm{SS}_{\mathrm{C}}$ & 1 & $5.69(28)$ & $21.19(177)$ & $5.82(52)$ & $82.17(413)$ & $8.99(349)$ & $807.85(510)$ & $0.55(40)$ & $-0.40(222)$ \\
\hline ASR & 222 & 1.44 & 4.83 & 0.93 & 83.20 & 1.57 & $11,154.82$ & 0.27 & 0.03 \\
\hline CV (\%) & & 5.76 & 6.46 & 6.18 & 7.48 & 8.73 & 8.94 & 18.08 & 31.77 \\
\hline
\end{tabular}

ORG: organic compound; SS's: group of substrates involving those with sand and savannah soil (standard substrate - SS); SS: substrate with absence of sheep manure (M) and carbonized rice husk (C) components; $S S_{M c}$ : group of substrates involving those with M and, or, C components (SS+M+C, SS+M, SS+C); $S S_{M+c}$ : substrate with M and C components $(\mathrm{SS}+\mathrm{M}+\mathrm{C})$; $\mathrm{SS}_{\mathrm{Mc}}$ : group of substrates involving those with $\mathrm{M}$ or $\mathrm{C}(\mathrm{SS}+\mathrm{M}, \mathrm{SS}+\mathrm{C})$; $\mathrm{SS}_{\mathrm{M}}$ : substrate with M components $(\mathrm{SS}+\mathrm{M})$; $\mathrm{SS}_{\mathrm{c}}$ : substrate with $\mathrm{C}$ components $(\mathrm{SS}+\mathrm{C})$. Relative increments: $100(x-y) / y$, where $x$ is the highest treatment average and $y$ is the lowest treatment average. NL: number of leaves; PH: plant height; SD: stem diameter; SFM: shoot fresh mass; SDM: aerial part dry mass; LA: leaf area. DR: root density; RS: ratio between root and shoot dry mass (g). All the results were significant at $1 \%$ probability, by the F test. 
Nutrient accumulation in micropropagated seedlings of 'Vitória' pineapple was studied by Baldotto et al. $(2009,2010)$, who verified the following accumulations, in g plant ${ }^{-1}: 3.16-21.22 \mathrm{~N}, 1.22-7.44 \mathrm{P}, 22.23-$ 113.20 K, 3.20-12.09 Ca, 1.14-11.83 Mg, at 150 and 90 days of acclimatization, respectively. In the present study, all accumulated nutrient values were higher. However, it is noteworthy that the time of 210 days (60 and 120 days more) of acclimatization was high enough for the plants to present higher growth and, nevertheless, greater accumulation of nutrients.

The unfolding of substrates with different compositions of organic material within each level of the factor cultivar is presented in mean contrasts (Table 6 and 7), according to Alvarez V. \& Alvarez (2006). Mean contrasts represent the real magnitude difference between the means of the compared treatments for the morphological and nutritional characteristics of the pineapple cultivars.

The contrast comparing the SDW of pineapple cultivars 'Pérola', 'Vitória', and 'Imperial' between the organic compound and the group of substrates containing SS (ORG vs SS's) showed that there were increases in the order of $36.87 \mathrm{~g}(366 \%), 24.01 \mathrm{~g}$ (270\%), and $20.39 \mathrm{~g}(259 \%)$, respectively, by the use of organic compound. In this sense, the contrast ORG vs SS's highlighted significant increases in all shoot morphological variables of the pineapple cultivars (Table 6).

Table 7 - Average contrasts, relative increments, average square of residue (ASR) and coefficient of variation (CV) for nutrients accumulation by 'Pérola', 'Vitória' and 'Imperial' pineapples in response to treatments of the substrate factor.

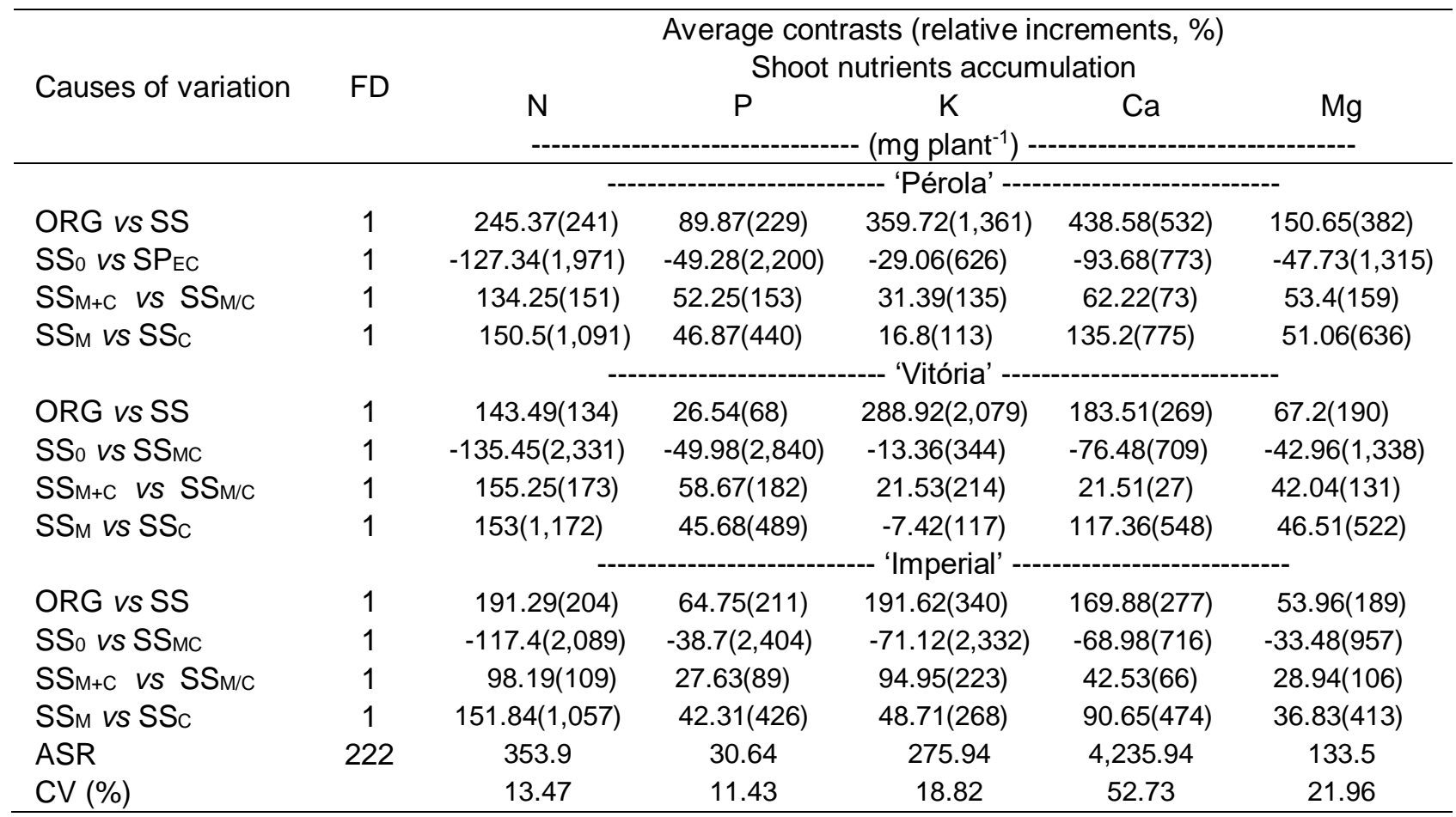

ORG: organic compound; SS's: group of substrates involving those with sand and savannah soil (standard substrate - SS); $\mathrm{SS}_{0}$ : substrate with absence of sheep manure (M) and carbonized rice husk (C) components; $\mathrm{SS}_{\mathrm{MC}}$ : group of substrates involving those with $\mathrm{M}$ and, or, $\mathrm{C}$ components $(\mathrm{SS}+\mathrm{M}+\mathrm{C}, \mathrm{SS}+\mathrm{M}, \mathrm{SS}+\mathrm{C})$; $\mathrm{SS}_{\mathrm{M}+\mathrm{C}}$ : substrate with $\mathrm{M}$ and $\mathrm{C}$ components $(\mathrm{SS}+\mathrm{M}+\mathrm{C})$; $\mathrm{SS}_{\mathrm{M} / \mathrm{C}}$ : group of substrates involving those with $\mathrm{M}$ or $\mathrm{C}(\mathrm{SS}+\mathrm{M}, \mathrm{SS}+\mathrm{C})$; $\mathrm{SS}_{\mathrm{M}}$ : substrate with M components (SS+M); $\mathrm{SS}_{\mathrm{C}}$ : substrate with $\mathrm{C}$ components $(\mathrm{SS}+\mathrm{C})$. Relative increments: $100(\mathrm{x}-\mathrm{y}) / \mathrm{y}$, where $\mathrm{x}$ is the highest treatment average and $\mathrm{y}$ is the lowest treatment average. NL: number of leaves; PH: plant height; SD: stem diameter; SFM: shoot fresh mass; SDM: aerial part dry mass; LA: leaf area. DR: root density; RS: ratio between root and aerial part dry mass (g). All the results were significant at $1 \%$ probability, by the $\mathrm{F}$ test.

The roots of 'Pérola', 'Vitória', and 'Imperial' pineapples were also significantly altered by substrates in the contrast ORG vs SS's (Table 6). In favor of ORG, RD increases in the order of 187, 212, and $116 \%$ were observed for cultivars 'Pérola', 'Vitória', and 'Imperial', respectively. However, RSR was favored by the SS group, with 266, 219, and 277\% increase, in the same order of cultivars.

The growth promotion of pineapple seedlings by the ORG substrate significantly increased $\mathrm{N}, \mathrm{P}, \mathrm{K}$, $\mathrm{Ca}$, and $\mathrm{Mg}$ content in the plants (Table 7). Cultivars 'Pérola', 'Vitória', and 'Imperial' showed increases of 241,134 , and $204 \%$ for $\mathrm{N} ; 229,68$, and $211 \%$ for $\mathrm{P}$; $1,361,2,079$, and $340 \%$ for $\mathrm{K} ; 532,269$, and $277 \%$ for $\mathrm{Ca}$; and 382, 190, and $189 \%$ for $\mathrm{Mg}$, respectively.

The superiority verified for the organic compound (ORG) in relation to substrates with savannah soil, sheep manure, and carbonized rice husk (SS's) 
was mainly due to the quality of the organic material used, composed of plant remains and animal excrement at several stages. The chemical and physical quality promoted by the composting process in ORG can be observed in Tables 1 and 2 .

The decomposition, polymerization or condensation of organic matter results in humified substances in the fractions humic acid (HA), fulvic acid (FA), and humin (HU). Baldotto et al. (2009) reported a significant effect of HA doses on root and root growth; N, P, K, $\mathrm{Ca}$, and $\mathrm{Mg}$ accumulation; and chlorophyll $\mathrm{a}-\mathrm{b}^{-1}$ ratio of micropropagated seedlings of 'Vitória' pineapple.

In addition, the living organic matter cannot be disregarded. Baldotto et al. (2010) demonstrated the importance of this item for pineapple cultivation when verifying that the combined use of $\mathrm{HA}$ and endophytic bacteria (Burkholderia spp.) promoted greater shoot growth compared to the control and to the isolated effect of these treatments.

The organic matter (OM) value of $69.2 \mathrm{~g} \mathrm{~kg}^{-1}$ is within the range considered good. Notwithstanding, Ribeiro et al. (1999) consider OM values of approximately $70 \mathrm{~g} \mathrm{~kg}^{-1}$ to be very good. According to Silva \& Mendonça (2007), OM is a fundamental factor for soil CEC, contributing with 20 to $90 \%$ of the CEC of mineral soils and, practically, all CEC of organic soils.

The CEC observed in ORG was $22.08 \mathrm{cmol}_{\mathrm{c}}$ $\mathrm{dm}^{-3}$, with a predominance of $\mathrm{Ca}^{2+}(47.55 \%)$ and $\mathrm{Mg}^{2+}$ (35.78\%), exceeding in $165.38 \%$ the highest CEC value observed among other substrates. In addition, saturation by exchangeable bases was $90.58 \%$. Studying the response of alternative substrates in the production of seedlings of vegetables and ornamental plants, Cabral et al. (2011) and Faria et al. (2016) found higher morphological performance for plants in substrates with CEC above $20 \mathrm{cmol}_{\mathrm{c}} \mathrm{dm}^{-3}$ and saturation by exchangeable bases above $70 \%$.

The contrast comparing the growth of pineapple cultivars between the substrate with absence of sheep manure (M) and carbonized rice husk $(\mathrm{C})$ and the group of substrates containing $\mathrm{M}$ and/or $\mathrm{C}$ (SS $\mathrm{SS}_{0}$ $\mathrm{SS}_{\mathrm{MC}}$ ) showed a significant difference in all morphological and nutritional characteristics (Table 6 and 7). In this contrast, there was superiority of the $S_{M C}$ group over the substrate with absence of $M$ and $C\left(S_{0}\right)$ in all shoot morphological variables of the pineapple cultivars (Table 6). This highlights that the non-use of organic components in the preparation of the substrate drastically reduces the performance of the acclimatization process of micropropagated pineapple seedlings. For example, LA values showed relative contrasts above 918\%, reaching 1,494\% (Table 6). The nutrient content of cultivars 'Pérola', 'Vitória', and 'Imperial' was: $1,971,2,331$, and $2,089 \%$ for $\mathrm{N} ; 151,27$, and $137 \%$ for $\mathrm{P} ; 626,344$, and 2,332\% for $\mathrm{K} ; 392,709$, and $194 \%$ for $\mathrm{Ca}$; and 1315,1338 , and $957 \%$ for $\mathrm{Mg}$, respectively (Table 7 ).

The superiority regarding the use of organic component corroborates the results of Moreira et al. (2006). The authors verified that the shoot and root morphology of micropropagated pineapple seedlings were lower when using only soil as a substrate component during acclimatization. Moreira et al. (2006) attributed the benefits of using organic component in the substrate mixture to the following factors: good plant support until rooting, little variation in substrate volume regarding moisture content, adequate water retention, and sufficient porosity to water drainage and aeration. The chemical factor (Tables 1 and 2) of the substrates should also be considered, since $\mathrm{SS}_{0}$ shows a lower fertility class than the other treatments.

The contrast $\mathrm{SS}_{\mathrm{M}+\mathrm{C}}$ vs $\mathrm{SS}_{\mathrm{M} / \mathrm{C}}$, which confronted the effects of the joint use of $M$ and $C$ on the same substrate $\left(\mathrm{SS}_{\mathrm{M}+\mathrm{C}}\right)$ with the effects of components $\mathrm{M}$ or $\mathrm{C}$ on separate substrates $\left(\mathrm{SS}_{\mathrm{M} / \mathrm{C}}\right)$, along with the contrast $S_{S}$ VS $S_{C}$, which compared the isolated effects of $M$ against $\mathrm{C}$, were significant for all variables analyzed (Table 6 and 7). $S_{\mathrm{M}_{+} \mathrm{C}}$ exceeded the $\mathrm{SS}_{\mathrm{M}} \mathrm{c}$ group in all shoot variables, $\mathrm{RD}$, and nutrient accumulation (Tables 6 and 7), evidencing the synergistic effect of components $\mathrm{M}$ and $\mathrm{C}$ when used in the same substrate. When $M$ and $C$ were used in separate substrates (SSM vS SSc), the highest morphological and nutritional contribution occurred in SSM (Tables 6 and 7).

The results of the chemical analysis of the substrates (Tables 1 and 2) show similar fertility classes between substrates SS and SS $+\mathrm{C}$ and between substrates $S S+M$ and $S S+M+C$ (Ribeiro et al., 1999). Thus, it can be inferred that the synergistic effects of the joint use of $M$ and $C$ on the substrate were the result of increases in physical attributes such as aeration and water retention.

In the acclimatization of micropropagated seedlings of pineapple cultivars 'Vitória' and 'Imperial', Mendonça et al. (2017) found beneficial effects from the use of goat manure on the substrate composition. This fact was attributed to the high amount of $\mathrm{N}$ present in the organic matter of goat manure, which is the main responsible for the production of new cells and tissues, and for the synthesis of vitamins, hormones, coenzymes, and alkaloids, in addition to being a component of chlorophyll molecules.

Rodrigues et al. (2004) reported low chemical activity of carbonized rice husk compared to organic materials such as humus. The authors emphasize that substrates with lower chemical activity may present a greater nutrient availability in solution, but their use must be preceded by chemical supplementation.

\section{Conclusions}

In the acclimatization phase, cultivar 'Pérola' presented a higher vegetative performance compared to cultivars 'Vitória' and 'Imperial' as regards shoot and root growth.

The nutrient accumulation pattern of cultivars was: 'Pérola' > 'Imperial' > 'Vitória', for $\mathrm{N}$ and $\mathrm{P}$; and 'Pérola' > 'Vitória' > 'Imperial', for K, Ca, and Mg.

Substrates Organoamazon®) (organic compound based on cattle, horse, chicken, and sheep 
manure, aged and carbonized rice straw, peat, sugarcane bagasse, grass clippings, galls and foliage) and $\mathrm{SS}+\mathrm{M}+\mathrm{C}(1: 1)$ [mixture of savannah soil and sand $(1: 1)$ + sheep manure + carbonized rice husk $(2: 1: 1 \mathrm{v} / \mathrm{v})]$ are recommended for the production of micropropagated seedlings of pineapple cultivars 'Pérola', 'Vitória', and 'Imperial', from in vitro culture.

\section{Acknowledgements}

The authors thank CNPq (Process 575587/2008-3) and SUFRAMA for funding the research, and CAPES for the scholarships.

\section{References}

Alvarez V VH, Alvarez GAM (2006) Comparações de médias ou testes de hipóteses? Contrastes! Boletim Informatibo SBCS 31(1):24-34.

Araújo RF, Siqueira DL, Cecon PR (2008) Multiplicação in vitro do abacaxizeiro 'smooth cayenne' utilizando benzilaminopurina (BAP) e ácido naftalenoacético (ANA). Ceres 55(5):455-460.

Baldotto LEB, Baldotto MA, Canelas LP , BressanSmith R, Olivares FL (2010) Growth promotion of pineapple 'Vitória' by humic acids and Burkholderia spp during acclimatization. Revista Brasileira de Ciência do Solo 34(5):1593-1600. doi: 10.1590/s010006832010000500012

Baldotto LEB, Baldotto MA, Giro VB, Canelas LP, Olivares FL, Bressan-Smith R (2009) Desempenho do abacaxizeiro 'Vitória' em resposta à aplicação de ácidos húmicos durante a aclimatação. Revista Brasileira de Ciência do Solo 33(4):979-990. doi: 10.1590/s010006832009000400022

Barboza SBSC, Graciano-Ribeiro D, Teixeira JB, Portes TA, Souza LAC (2006) Anatomia foliar de plantas micropropagadas de abacaxi. Pesquisa Agropecuária Brasileira 41(2):185-194. doi: 10.1590/s0100-204x2006000200002

Berilli SS, Carvalho AJC, Freitas SJ, Berilli APCG, Santos PC (2011) Crescimento de mudas de abacaxizeiro cv Vitória durante a aclimatação em função do seu tamanho inicial. Revista Brasileira de Fruticultura 33(1):632-637.

Berilli SS, Freitas SJ , Santos PC, Oliveira JG, Caetano LCS (2014) Avaliação da qualidade de frutos de quatro genótipos de abacaxi para consumo in natura. Revista Brasileira de Fruticultura 36(2):503-508. doi: 10.1590/0100-2945-100/13

Bregonci IS, Schmildt ER, Coelho RI, Reis EF, Brum VJ, Santos JG (2008) Adubação foliar com macro e micronutrientes no crescimento de mudas micropropagadas do abacaxizeiro cv Gold [Ananás comosus (L) Merrill] em diferentes recipientes. Ciência e Agrotecnologia 32(3):705-711.
Caetano LCS, Ventura JA, Balbino JMS (2015) Comportamento de genótipos de abacaxi resistentes à fusariose em comparação a cultivares comerciais suscetíveis. Revista Brasileira de Fruticultura 37(2):404-409. doi: 10.1590/0100-2945-117/14

Catunda PHA, Marinho CS, Gomes MMA, Carvalho AJC (2008) Brassinosteróide e substratos na aclimatização do abacaxizeiro 'Imperial'. Acta Scientiarum Agronomy 30(3):345-352.

Ribeiro AC, Guimarães PTG, Alvarez V VH (eds) (1999) Recomendações para o uso de corretivos e fertilizantes em Minas Gerais 5ª Aproximação. UFV. $359 p$.

Cunha Filho FN, Torres AC, Charchar JM (2008) Avaliação de substratos na produção de mudas do abacaxizeiro ornamental [Ananás comosus (L) Merr var bracteatus (Lindl) Coppens \& F Leal] em condições de casa de vegetação. Plant Cell Culture Micropropagation 4(2):70-75.

Faria JCT, Caldeira MVW, Delarmelina WM, Rocha RLF (2016) Substratos alternativos na produção de mudas de Mimosa setosa Benth. Ciência Florestal 26(4):1075-1086.

Fráguas CB, Dornelles CMV, Lima GPP (2009) Benzilaminopurina e ácido naftaleno acético na indução e multiplicação in vitro de gemas de abacaxizeiro da cultivar 'IAC Gomo-de-mel'. Ciência Rural 39(6):16821687. doi: 10.1590/s0103-84782009000600008

Malavolta E, Vitti GC, Oliveira SA (1997) Avaliação do estado nutricional das plantas: princípios e aplicações. Associação Brasileira para Pesquisa da Potassa e do Fosfato. 319p.

Mendonça V, Mendonça LFM, Pereira EC, Leite GA, Costa JM, Medeiros FMC (2017) The growth and nutrition of pineapple (Ananas comosus L) plantlets under diferents water retention regimes and manure. African Journal of Agricultural Research 12(21):18521860. doi: 10.5897/ajar2016.11702

Moreira MA, Carvalho JG, Pascal M, Fráguas CB, Silva $A B$ (2006) Efeito de substratos na aclimatização de mudas micropropagadas de abacaxizeiro cv Pérola. Ciência e Agrotecnologia 30(5):875-879. doi: $10.1590 /$ s1413-70542006000500008

Murashige T, Skoog F (1962) A revised medium for rapid growth and bioassays with tobacco tissue culture. Physiologia Plantarum $15: 473-$

497. doi.org/10.1111/j.1399-3054.1962.tb08052.x

Oliveira-Cauduro Y, Lopes VR, Bona CM, Alcantara GB, Biasi LA (2016) Micropropagação de abacaxizeiro com enraizamento in vitro e ex vitro. Plant Cell Culture \& Micropropagation 12(2):53-60. 
Reinhardt DHRC, Cabral JRS, Souza LFS, Sanches NF, Matos AP (2002). Pérola and Smooth Cayenne pineapple cultivars in the state of Bahia Brazil: growth flowering pests diseases yield and fruit quality aspects. Fruits 57(1):43-53. doi.org/10.1051/fruits:2002005

Rodrigues AA, Mendonça RMN, Silva AP, Silva SM, Pereira WE (2010) Desenvolvimento vegetativo de abacaxizeiro 'Pérola' e 'Smooth Cayenne' no Estado da Paraíba. Revista Brasileira de Fruticultura 32 (1):126-134.

Rodrigues TM, Paiva PDO, Rodrigues CR, Carvalho JG, Ferreira CA, Paiva R (2004) Desenvolvimento de mudas de bromélia-imperial (Alcantarea imperialis) em diferentes substratos. Ciência e Agrotecnologia 28 (4):757-763. doi: 10.1590/s1413-70542004000400005

Sampaio AC, Fumis TF, Leonel S (2011) Crescimento vegetativo e características dos frutos de cinco cultivares de abacaxi na região de Bauru-SP. Revista Brasileira de Fruticultura 33 (3):816-822.

Santos PC, Freitas SJ, Freitas MSM, Sousa LB, Carvalho AJC (2011) Produção de mudas do tipo rebentão utilizando coroas de três cultivares de abacaxi inoculadas com fungos micorrízicos. Revista Brasileira de Fruticultura 33 (3):954-961.
Silva AB, Pascal M, Castro EM, Ramos JD, Braga FT, Araújo AG (2012) Luz natural, sacarose e fitorreguladores na anatomia foliar e crescimento in vitro de abacaxizeiro micropropagado. Plant Cell Culture \& Micropropagation 8(1-2):1-9.

Silva IR, Mendonça ES (2007) Matéria orgânica do solo. In: Novais RF, Alvarez V VH, Barros NF, Fontes RLF, Cantarutti RB, Neves JCL (Eds) Fertilidade do solo, SBCS. p.275-374.

Ventura JA, Costa H, Caetano LCS (2009) Abacaxi 'Vitória': uma cultivar resistente à fusariose. Revista Brasileira de Fruticultura 31(4): I-II. doi: 10.1590/s010029452009000400001

Viana ES, Reis RC, Jesus JL, Junghans DT, Souza FVD (2013) Caracterização físico-química de novos híbridos de abacaxi resistentes à fusariose. Ciência Rural 43(7):1155-1161. doi: 10.1590/s010384782013005000075 